\title{
O modernismo entra em campo: o caso Wisnik*
}

\author{
Pedro Meira Monteiro
}

Tratar de um livro como Veneno remédio: o futebol e o Brasil, de José Miguel Wisnik, é um desafio delicado, por duas razōes principais.

Em primeiro lugar, pelo seu escopo: Veneno remédioé uma obra poderosa que se abre para a história das interpretações do Brasil e, portanto, para a história das ciências sociais e da crítica literária e cultural no país no século XX. É contra tal horizonte que Wisnik arma suas hipóteses, que se revelam especialmente ao final, quando é postulada sua convergência em relação às teses formadoras dos grandes ensaios de 1930, notadamente de Sérgio Buarque de Holanda e Gilberto Freyre. Aí surge o primeiro desafio lançado ao leitor, já que em Veneno remédio o futebol é uma espécie de matriz hermenêutica fundamental. Em outras palavras, o futebol não é apenas o futebol: ele é o signo de outra coisa. Ou, antes, por ser fecundo como é, ele dispara outros signos, que são capazes de interrogar-se a si mesmos, mergulhando o leitor na batalha dos signos, que é, a rigor, a significação do Brasil - eis aí o tema por excelência dos grandes ensaios de interpretação nacional.

Uma dificuldade adicional para a interpretação deste livro está em algo que se poderia identificar como seu princípio mimético, que se expressa à perfeição na ideia da genialidade. A genialidade é uma questão central para a compreensão do futebol, e para a compreensão daquilo que o futebol permitiria compreender, ou intuir, sobre a formação social e cultural brasileira. No entanto, a "genialidade" está também na forma do livro, na simulação
* Esta é uma versão consideravelmente revista e aumentada de uma palestra proferida junto ao programa de pós-graduação do Departamento de Sociologia, na Faculdade de Filosofia, Letras e Ciências Humanas da Universidade de São Paulo, em 2 de setembro de 2009. Agradeço a Nadya Guimarães, pelo estimulante convite, e a José Miguel Wisnik, pela presença e pelo diálogo franco e fraterno. André Pires, Arcadio Díaz Quiñones, Hélio de Seixas Guimarães, Bruno Carvalho, Joaquim Brasil Fontes e Lilia Schwarcz foram ainda leitores do texto. A todos eles, e aos colegas e estudantes que estiveram debatendo naquela noite na USP, agradeço pelas reaçôes e sugestôes. 
de um campo de questôes em que o intérprete joga uma partida arriscada. Em suma, o escritor é um símile do jogador. E o leitor, como o espectador, se vê diante de lances ousados, que não poucas vezes guardam a surpresa daqueles movimentos a um só tempo bruscos e precisos, capazes de alterar o rumo da partida hermenêutica e deslocar completamente a atenção do leitor para algo que estava lá, mas que ele, leitor, não havia percebido. Em outros termos, embora ainda emprestando metáforas ao futebol, os passes são constantes, e são impressionantes os deslizamentos de sentido, movimentos cuja complexidade exige atenção redobrada e sensibilidade para o conjunto. Ainda aqui, trata-se de algo que remete aos ensaios, ou mais propriamente à sua forma, em que "fortuna e jogo" são essenciais, como lembra - ou advoga - Adorno (cf. Adorno, 1991, p. 4).

Em segundo lugar, outra razão por que é delicado trabalhar com um livro como este é o fato de não se tratar, ao fim, apenas de uma peça hermenêutica, já que o futebol não é um sustentáculo qualquer para a aventura da interpretação do Brasil. Veneno remédio é um livro sobre o futebol, e como tal deve ser lido. Um livro que talvez somente um verdadeiro amante platônico do futebol possa compreender em toda a sua extensão. Ou talvez, em termos menos platônicos, só um jogador de futebol poderia entendê-lo completamente. Há nele uma erudição futebolística que a prosa fluida de Wisnik não chega a disfarçar. E aqui o problema é muito próximo daqueles que os leitores de Wisnik encontram quando se trata de seus textos que abordam a música. São em geral ensaios que exigem, no caso dos "leigos", um tremendo esforço e desejo de aproximação. Nesse sentido, contudo, o problema é também a sua solução: o veneno é o remédio. Ocorre que a relativa opacidade desse mundo de referências futebolísticas ou musicais, e a dificuldade mesma de penetrar outra linguagem - seja a dos sons, seja a dos corpos que se movimentam em campo -, acicata o leitor, provocando-o e, não poucas vezes, obrigando-o a uma espécie de entrega furiosa ao texto.

Seria em todo caso um terrível engano imaginar que o futebol é uma mera desculpa para falar do Brasil. Imaginar que o futebol é um significante vazio, que poderia ser substituído por outro, seria uma maneira gritante de não entender, ou de ler mal, o livro. Em suma, se o leitor não se entregar às descrições e não se comover com o drama e a beleza plástica do futebol, se não compreender o aspecto dramático das estratégias e das formações, então é provável que a jornada hermenêutica termine mal, e que ao fim ninguém se entenda. 
É claro que a imagem de um platônico amante do futebol é apenas uma brincadeira. Na verdade, um saudável princípio materialista, que convém sempre advogar, faz supor que é preciso cair em campo para compreender aquilo de que Wisnik está falando. Mas o interessante é que, em todo o caso, o autor fala de dois campos, que apontam para as ideias e para suas sombras. E o futebol não joga exclusivamente com aquilo que foge do ideal, isto é, numa perspectiva platônica, com o corpo, ou a matéria vil. Ao jogar com outras camadas, o futebol é fundamentalmente o sintoma - no sentido psicanalítico em que vaza o texto de Wisnik - de uma formação. Afinal, ele é a parte apenas visível em que processos mais profundos se entremostram como enigma. Enigma que pode ser ao mesmo tempo um problema e uma solução. (Como em qualquer processo psicanalítico, há que tirar forças dos nossos "problemas", que é tudo o que realmente possuímos.) Em suma, pode-se supor que, no fundo, José Miguel Wisnik coloca o futebol no divã, e o que resta da análise, deitado em berço (ou num divã) esplêndido, é a figura suntuosa do Brasil.

Todos esperamos que essa figura, deitada no divã, jamais se pareça ao lateral Roberto Carlos, que causa em Wisnik, como causou em tantos de nós, uma profunda revolta, quando arrogantemente se deitou como que num canapé, esperando que a partida com o Japão passasse, na Copa da Alemanha. Roberto Carlos que, segundo uma passagem sardônica de Veneno remédio, na fatídica partida de 1998 contra a França, se distraía "arrumando a meia como um cortesão decadente enquanto a bola era centrada para a área brasileira, culminando no gol fatal da desclassificação" (Wisnik, 2008, p. 386).

Antes que alguém atrapalhadamente suponha que o futebol não é coisa séria, vale lembrar que Roberto Carlos é um dos mais "sintomáticos" jogadores no livro de Wisnik. Nele está cifrada uma arrogância que não é apenas o fruto espúrio do império da propaganda sobre as atividades lúdicas. $\mathrm{Na}$ atitude de Roberto Carlos está representada a incapacidade de descolar-se de um pedestal que a certeza sobre a própria excelência, sobre a diferença enobrecedora, acaba convertendo numa prisão.

Vale lembrar que, já num livro como $O$ som e o sentido: uma outra história das músicas (cf. Wisnik, [1989]* 1999), a dimensão sacrificial era flagrada na própria fundação da música. É razoável supor que essa dimensão reapareça, agora em outro campo, na exposição exemplar - ainda aqui uma espécie de sacrifício do indivíduo em prol do reconhecimento da coletividade - dos jogadores, já que cada um deles se torna uma peça capaz de revelar a tragédia de um país que tem uma autoimagem ora inflacionada ora deflacionada.
* A data entre colchetes refere-se à ediçāo original da obra. Ela é indicada na primeira vez que a obra é citada. Nas demais, indicase somente a edição utilizada pelo autor (N. E.). 
1. O ensaio, originalmente publicado em 2003, comporia em seguida a coletânea Sem receita: ensaios e cançôes (Wisnik, 2004). $\mathrm{Na}$ linha oscilante entre a música $\mathrm{e}$ a crítica, ou no balanço irresolvido entre o músico e o crítico, resta lembrar que não se compreende a escrita de "Machado maxixe" sem a composição, no mesmo tempo, da trilha sonora do balé Nazareth, do Grupo Corpo. Em entrevista a Luiz Tatit, João Camillo Penna e Arthur Nestrovski, Wisnik lembra que “'Cruz, perigo!!' é uma polca que Nazareth escreveu com 15 ou 16 anos, o que é impressionante. De 1878, se não me engano; contemporânea do Pestana [personagem do conto de Machado de Assis]. Tem o acompanhamento característico de polca, na mão esquerda, mas a mão direita toca um motivo amaxixado e repicado por oitavas - são dois acontecimentos simultâneos na mão direita. Amaxixados na mão direita e polcados na esquerda. A polca amaxixada está ali como se fosse o palimpsesto da música brasileira: como essa música se formou, de onde veio, para onde vai, as duas coisas ali juntas, formando uma textura em três planos. Isso foi usado na trilha, com espelhos. Vai-se entrando em 'Cruz, perigo!!' pela porta de trás: os elementos vão aparecendo pouco a pouco, através dos seus retrógrados e suas inversōes, em superposiçốes politonais, o que não deixa de ser também uma alusão a Darius Milhaud, que esteve no Brasil em 1917-1918, que considerava Nazareth o maior compositor brasileiro, entre eruditos e populares, e que escreveu Saudades do Brasil [1921] e Le boeuf sur le toit [1919] com elementos de inspiração em parte nazaretiana, tratados por meio da técnica politonal que Milhaud estava naquele momento criando e introduzindo no contexto da música francesa” (Wisnik, 2004, pp. 440-441).
Trata-se do "tudo ou nada", contra o qual, aliás, qualquer processo psicanalítico se insurge, porque, afinal, o paciente - neste caso, o Brasil - que inicia o seu tratamento tem que aprender a lidar com aquilo que tem, o que significa investir numa profunda desidealização, para finalmente pular fora daquela variação "ciclotímica" do tudo ou nada, que o ouvido musical e analítico de Wisnik revisita tantas vezes, para referir-se, já nas últimas páginas de Veneno remédio, a Machado de Assis, num momento em que a tese do livro ganha cores fortes:

Se Machado de Assis realiza em obra, disfarçadamente, aquilo que a sociedade abafada que ele descreve faria supor impossível (a atualidade antecipatória de uma criação original no campo intelectual), o futebol brasileiro torna possível em campo aquilo que a sociedade brasileira sistematicamente não realiza (democracia racial em ato, elevação dos pobres à máxima importância, competência inequívoca no domínio de um código internacional). Para que seus dons se irradiassem para áreas menos lúdicas, seria preciso passar por algo como uma segunda abolição da desigualdade (para além da dicotomia de raças) e ao mesmo tempo por uma cura do dispositivo doentio segundo o qual o país é ou receita de felicidade ou fracasso sem saída - ou total ou nulo, ou panaceia ou engodo, ou paradisíaco ou infernal. A meu ver, essa é, aliás, a precondição imaterial de qualquer outra mudança (Wisnik, 2008, p. 408).

Machado de Assis já se tornara futebol na análise de Wisnik, no magnífico ensaio "Machado maxixe: o caso Pestana”, em que o crítico e o músico sondam a forma como, no plano da ficção, o grande escritor capturara o amaxixamento da polca, que é uma espécie de vitória modernista avant la lettre, quando a singularidade do mundo sincopado das ruas (leia-se, do mundo afro-brasileiro das ruas do Rio de Janeiro) atinge a forma europeia, meio quadrada, da polca, e lhe dá aquele gostinho de requebro, de um meneio malicioso, da surpresa constante daquilo que se posiciona e se projeta entre o tempo e o contratempo ${ }^{1}$. Enfim, o jogo de corpo com o tempo permite que de repente, num momento propriamente epifânico, a forma europeia seja passada para trás, driblada numa síncope, sem que no entanto sua força e sua matriz se percam.

Machado de Assis não era ainda um antropófago oswaldiano, mas, ao menos nessa jogada, Wisnik é um modernista puro-sangue, já que a questão toda não reside apenas na negação desse "outro lado", que é o que a disciplina marcial das potências centrais pode oferecer, mas está, isto sim, na possibilidade de englobar o outro e adicionar-lhe esse grão gracioso de sal que 
está na música, na literatura, no futebol. Indo às raias de uma provocação: a promessa do futuro da civilização não virá do mundo desenvolvido, mas de sua periferia. Uma profecia se guarda aí, nessa análise do que virá. Como na canção, o tempo da profecia se estampa na flexão verbal que só ao poeta é dado experimentar: "Virá que eu vi”. Eu-crítico vejo o futuro melhor, no futebol, na música.

Sigo entretanto com uma anedota, que me permite adentrar o texto de Wisnik, que aliás, devo alertar, não será aqui resenhado. Esta reflexão não é propriamente uma análise de Veneno remédio, mas é tão somente uma provocação que a leitura do livro de José Miguel Wisnik torna urgente para o autor deste artigo, no quadro mais amplo de uma pesquisa sobre o imaginário latino-americanista de Sérgio Buarque de Holanda. Um imaginário que permite, finalmente, comparar Sérgio Buarque a Richard Morse. A hipótese norteadora da pesquisa, sem a qual minha própria aproximação do livro de Wisnik não se deixa compreender, é que $O$ espelho de Próspero, de Morse, seria uma espécie de leitura exagerada de Raízes do Brasil, com a aposta um tanto despudorada na via ibérica, na diferença brasileira, ou latino-americana (ou ainda ibero-americana), em relação a outra via civilizacional, moderna, ocidental e ultrassecularizada. Tal via secularizada seria aquela tomada pela Europa de aquém-Pireneus e, mais especificamente, pela Europa protestante, que por sua vez teria gerado o outro lado da América, isto é, a América puritana. Uma América desencantada, esvaziada de todo segredo e mito, entregue à faina do trabalho metódico e a uma recompensa que só pode guardar-se no íntimo inescrutável do sujeito ${ }^{2}$. Em termos weberiano-futebolísticos, a taça se guarda, como possibilidade, no íntimo atormentado do indivíduo, que não irá reparti-la com ninguém.

Trata-se enfim de uma parte da América, os Estados Unidos, que é o demônio de Morse, e é também o demônio de juventude de Sérgio Buarque de Holanda ${ }^{3}$. Tal é o espelho que fornece a imagem invertida do que o intelectual deseja. É curioso que o referente (muitas vezes silencioso) de Raízes do Brasil sejam os Estados Unidos. Um referente que finalmente se explicita em Richard Morse, e que se entremostra ainda em José Miguel Wisnik, cuja tese forte de início é que o futebol, tal qual se joga no Brasil, seria impensável nos Estados Unidos. Mas vamos à anedota.

Vivendo e trabalhando nos Estados Unidos há quase uma década, passei boa parte desse tempo resistindo a uma palavra: training. Eu ouvia os colegas norte-americanos referindo-se à formação acadêmica como um academic training: fulano foi treinado em Princeton, sicrano foi treinado

2. O tema fornece um dos eixos de um livro sobre "as heranças de Raizes do Brasil'. Algumas de suas principais teses apareceram recentemente em um ensaio publicado na revista do Cebrap. Cf. Monteiro (2009).

3. Ver, a propósito, a resenha do Ariel, de José Enrique Rodó, que Sérgio Buarque de Holanda publicou na Revista do Brasil em 1920, quando tinha apenas 18 anos de idade (cf. Holanda, 1996). 
na Unicamp, na USP etc. Foi preciso ler o livro de Wisnik sobre o futebol para que eu compreendesse as origens mais remotas e persistentes de minha própria resistência àquela palavra.

Ao fim, nossa formação cultural ibérica, bacharelesca, leva a crer que a "formação acadêmica" é algo nobre demais, propriamente excepcional, para caber na ideia de um simples "treinamento", que além de ser uma palavra que desenobrece o acadêmico, é um vocábulo que pode muito bem desencadear fantasias democráticas: de um ponto de vista liberal, qualquer um poderia treinar e vir a tornar-se excelente em sua área. Os pressupostos liberais desse potencial democrático do "treinamento" dificilmente passam pela rede de uma análise circunstanciada das condições de acesso ao treinamento e aos centros de excelência, que estão regidas, Bourdieu dixit, por um complexo conjunto de dispositivos de acesso que, de fato, não são de todos.

É portanto a própria noção de universalidade que está em questão no embate entre as palavras "formação" e "treinamento". Sem contar, é claro, com o vertiginoso problema do "talento", que traz ao primeiro plano da análise uma miríade de histórias subjetivas, irredutíveis ao esquema racionalizante que permitiria compreender o "acesso", seja pela via da "formação", seja pela do "treinamento". De toda forma, as palavras são sintomáticas, sempre. E no entanto, por razões várias, de ordem linguística inclusive, fiz as pazes com a palavra "treinamento". Mas não teria sido possível entender os motivos mais recônditos de meu próprio incômodo não fora a leitura de Veneno remédio. Vejamos.

4. Os títulos e subtítulos que povoam Veneno remédio não apenas jogam amiúde com uma duplicidade que é a matéria mesma de análise, mas investem profundamente na noção, de corte platônico e derridaico, de um phármakon, que é afinal o veneno-remédio em questão. Cf. Derrida (1972).
Numa seção intitulada "A lama e a grama" ${ }^{4}$, anuncia-se aquilo que plausivelmente forma a coluna mestra da discussão de Wisnik em torno do futebol, uma atividade cultural que, afinal, oscila entre os extremos da "determinação" e da "indeterminação":

Antes de mais nada, o futebol imprime aos jogos pré-modernos a norma burguesa, mas mantendo uma margem significativa de ruralidade, uma dimensão telúrica indispensável para o entendimento de sua apropriação por outras culturas, de seu progressivo interesse policlassista e multiétnico, e de sua vocação transcontinental. Ao contrário do basquete, do vôlei, do hóquei ou do futsal, jogos posteriores de espírito definitivamente citadino, praticados sobre terrenos pavimentados e geralmente cobertos, o futebol se joga ao ar livre, sobre a terra e sobre a grama, num espaço generoso e exposto à natureza, proliferando não só na Europa mas nas periferias do mundo, nos clubes como nas várzeas (Wisnik, 2008, p. 95). 
Talvez devamos prestar menos atenção aqui a essa suposta ruralidade, e muito mais à questão telúrica, bem como aos vocábulos que, neste trecho, ressumam uma produtividade livre, quase panteísta ("ar livre”, "generoso", "proliferando", "policlassista", "multiétnico", e o significativo plural em "periferias do mundo").

A promessa do futebol como vetor democratizante nunca se apaga em Veneno remédio. Haveria contudo que qualificar tal aspecto democrático, que a rigor não se liga, em José Miguel Wisnik, àquela "norma burguesa" de que supostamente nós nos desviamos (ou que utilizamos com desfaçatez) e que gera uma discussão nem sempre galante nos meios intelectuais brasileiros, sobre, justamente, o lugar exato das ideias em toda a nossa história.

Ocorre que em Wisnik o futebol tem poderes extraordinários como instrumento de compreensão da formação social, de seus enigmas, seus impasses e suas promessas. A “quadratura do circo", a propósito, é uma noção que retorna todo o tempo nessa grande perquirição do Brasil, como aquelas imagens ou palavras que não abandonam o paciente na psicanálise: interrogantes que insistem, falando do fundo desiderativo que forma o sujeito. Sujeito que, aqui, é o próprio escritor-jogador, que carregará esse circo e esse quadrado pelo resto da partida hermenêutica, como um talismã sagrado, uma matriz em que se contêm os segredos da (sua) coletividade.

O “circo" em questão, a que se liga a própria bola e seus atributos mágicos de completude e infinitude, expressa a transcendência em que se funda o sentido primitivo da pertinência ao grupo e ao cosmos, mas expressa também uma impureza que já podemos aqui relacionar com aquela dialética entre a lama e a grama, e um olhar embalado na cantiga modernista recairá especialmente naquilo que brota, é claro, desse lamaçal em que nos metemos, ou desse lamaçal que somos.

Sobre o quadrado e o círculo como elementos arquetípicos que regem também a imaginação de Wisnik, vale a pena prestar atenção a mais uma passagem de Veneno remédio, que aparece imediatamente antes da passagem recém-referida:

O "circo" é também o círculo impuro, incompleto, festivo e turbulento, da dádiva-dívida a se perder na noite dos tempos - em que a perfeição geométrica e as construçôes simbólicas são corroídas pela positividade da vida real. O futebol é a quadratura do circo: a passagem necessariamente incompleta de um mundo ao outro, com aquela sobra irredutível e não racionalizável (um valor $\pi$ antropológico) que não se esgota na quantificação dos resultados numéricos, na lógica moderna do 
5. Vale a pena, aqui, retomar o debate a partir das sugestôes de Silviano Santiago, em recente aproximação que promove entre Raizes do Brasile El laberinto de la soledad. Ali, lê-se que se deveria "tomar um segundo cuidado [o primeiro cuidado se referia ao compromisso com uma democracia 'à la brasilienne', como a que defenderia, em princípio, José Murilo de Carvalho] no tratamento do conceito de cordialidade. Trata-se de um indecidivel [indécidable, em francês], como ensina Jacques Derrida. No livro Disseminação [Dissémination], lemos que o elemento indecidível, no caso a cordialidade, produz um efeito de meio: meio como elemento que contém ao mesmo tempo dois termos (amizade/ inimizade), meio, ainda, por o significado se manter entre dois termos (concórdia/discórdia). Filosoficamente, o indecidivel não se deixa compreender pela oposição binária e, no entanto, a habita, resiste-lhe e a desorganiza, sem jamais constituir um terceiro termo, sem jamais dar lugar a uma solução na forma da dialética especulativa”. Cf. Santiago (2006, p. 243). jogo, e cujos conteúdos não se deixam nomear. O futebol pôs em jogo, claro que sem premeditar o efeito, uma zona limiar de tempos culturais que acabou fazendo dele um laboratório demonstrativo das culturas e um ponto de interrogação sobre o destino da civilização (Idem, p. 94).

A clave em que se move Wisnik nos autoriza, aqui como em outros momentos da leitura, a uma parada em busca de fôlego.

O que é o tal "valor $\pi$ antropológico"? O que sobra nesse movimento da quadratura do circo, que resto bendito é este que não chega nunca a consumir-se na passagem de uma deliciosa desordem dionisíaca ao traçado apolíneo do esporte "moderno"?

Um leitor de Veneno remédio reconhecerá aí, imediatamente, a contraposição entre o futebol-prosa e o futebol-poesia, nos termos de Pasolini, tão fundamentais para a imaginação poética do próprio Wisnik, que encontra na leitura dramática do cineasta e poeta italiano uma chave para a compreensão daquela variável $(\pi)$ que, nas ondas dos leitores de Derrida, porventura tem a ver com um indecidivel que é sempre motor, e sempre marginal 5 . Em termos academicamente menos nobres, e com certeza mais pobres, trata-se do segredo do Brasil.

Arriscando um curto-circuito explicativo, suponho que Wisnik tenha, em seu livro, declarado guerra à possibilidade de subsumir o futebol - se é que é mesmo ao futebol que estamos nos referindo a esta altura - à ideia de uma finalidade que se contém já no início da partida. O que lhe interessa é antes a "positividade da vida real" que conspira contra a metafísica do futebol moderno, que é a figuração mesma de um mundo desencantado, prosaico, de que se excluiu a magia do poético, abrindo alas ao domínio absoluto da técnica, da previsibilidade, do treinamento. Nos termos de Pasolini, explicados por Wisnik, no modelo do futebol poético "o gol resultaria não de triangulações metodicamente concatenadas ou de cruzamentos com causa e efeito, mas de irrupções individualistas e de aproximações em ondas concêntricas, de cruzamentos paradoxais das causas com os efeitos" (Idem, p. 116).

Não à toa, a figura resultante do desenho pasoliniano (ou wisnikiano) do futebol poético é a elipse, que no jogo semiótico convoca a não linearidade, e permite ver que o que está em questão não é simplesmente uma idealizada malemolência tropical. O que está em questão é o desvio como potência, o drible como forma e o jogo como matriz sociológica. Seria uma má leitura atribuir a Veneno remédio o elogio conclusivo da mestiçagem, ou da norma 
tropical. Não parece correto tropicalizar, ou "freyrinizar" completamente o livro de Wisnik, ainda que, de fato, em meio ao ensaio, erga-se a promessa multiétnica, que atinge em cheio o problema da idealização e da sublimação do mestiço, tema tão candente para nós hoje, dentro e fora do Brasil.

Mas em Veneno remédio a mulata não é a tal, embora haja, convém insistir, um mulato pairando soberano sobre o livro, como um signo bendito a lembrar-nos do que somos capazes. A imaginação do professor de literatura não deixa escapar, por um momento sequer, a sombra de Machado-maxixe, a ponto de, no parágrafo derradeiro, o futebol ser provocativamente considerado o "emplasto Brás Cubas que deu certo" (Idem, p. 430).

Como parêntese teórico, não custa lembrar que o "homem cordial" é, em Veneno remédio, a projeção sociológica, ou poética, dessa concepção derridaica de uma droga que contém em si a perdição e a salvação. (Salvação é uma palavra, aliás, muito saborosa, já que sua etimologia remete a uma cura delicada, enquanto a imaginação corrente a refere a uma cura brutal, como o será qualquer salvação política.)

Mais que uma síntese plácida de opostos, o "homem cordial” aparece em Veneno remédio a partir da precisa discussão de uma matriz sociológica que aponta para a clássica "dialética da malandragem" de Antonio Candido, e a discussão sobre a ordem e a desordem. Nos termos que Wisnik vai buscar a Fernando Novais, o dilema de Raízes do Brasil seria o seguinte: "Se o Brasil permanece Brasil não se moderniza, se se moderniza deixa de ser Brasil" (Idem, p. 418).

O impasse é a própria forma do livro de Sérgio Buarque de Holanda, mas é importante, em todo caso, lembrar que Sérgio corre paralelo a Freyre na conclusão de Veneno remédio, num momento em que a figura paradigmática do mulato se torna um emblema que, a nós, pode logo lembrar a leitura freyriana da cordialidade, a partir da segunda edição de Sobrados e mucambos, de 1951, quando o homem cordial é explicitamente associado à figura do mulato (cf. Freyre, 2003, pp. 790-791). A identificação, diga-se de passagem, aproxima Freyre das conceituações de Cassiano Ricardo mais que das de Sérgio Buarque de Holanda ${ }^{6}$.

Vale lembrar, uma vez mais parafraseando Caetano Veloso, que em Veneno remédio há ainda algo que sopra, dizendo o tempo todo que "aqui embaixo a indefinição é o regime”. Mas, como em Caetano, a dança graciosa do Brasil é o outro lado de um brutal déficit de direitos: o potencial democrático do homem cordial, sua capacidade de amoldar-se, de transigir, de negociar, de não se aplastar diante da norma, é também a sua eficácia em confundir as esferas
6. Para o debate sobre o "homem cordial", ver o texto de Cassiano Ricardo e a carta de Sérgio Buarque de Holanda ao próprio Cassiano na edição comemorativa dos setenta anos de Raizes do Brasil. Cf. Holanda (2006). 
7. A referência a Derrida naturalmente não esgota a questão dos "restos" não simbolizáveis, que apontam para o cruzamento entre a psicanálise e a literatura, onde frequentemente se situa a imaginação de Wisnik. A referência tampouco se esgota no próprio autor francês: no âmbito de uma discussão sobre o símbolo nacional, é bastante conhecido o solo fértil que o desconstrucionismo encontrou nos chamados "estudos póscoloniais", de especial penetração na academia anglófona. Um ensaio paradigmático, neste sentido, é o de Homi Bhabha, intitulado, a propósito, "DissemiNation: time, narrative, and the margins of the modern nation" (cf. Bhabha, 1990). do público e do privado, em passar por cima do desconhecido para salvar o amigo, elevando o famigerado "jeitinho" à norma social. Quando a questão das classes sociais assoma, o homem cordial é então plenamente benéfico (porque é a defesa potencial contra o arbítrio que vem de cima) e plenamente maléfico (é o rico que só transa o rico, reativando o preconceito secular contra o pobre, que no Brasil é uma face logo visível e odiosa, com raízes de fato profundas).

Mas voltemos àquele misterioso e produtivo "valor $\pi$ antropológico". Afinal, literalmente, ali se agita a incógnita do Brasil.

Numa pequena e preciosa seção de Veneno remédio, intitulada "Diferença”, que se segue a uma seção denominada "O técnico", são novamente os princípios da ordem e da desordem, tão fundamentais para a discussão modernista brasileira, e tão fundamentais para a leitura que Antonio Candido faz da própria literatura brasileira, que estão em tela. Após uma discussão sobre o domínio técnico do espetáculo futebolístico, e sobre a batalha racionalizante contra as "instâncias fragmentárias, plurais e polimorfas do jogo espalhado pelo campo", o autor faz o que seria o elogio do "princípio rebelde do imprevisível, que se expressa em tudo aquilo que o jogo tem de incontrolável, desde o seu destino mais geral até o mínimo 'detalhe' definidor” (Wisnik, 2008, p. 131).

Eis então que a diferença em questão revela-se menos o princípio de uma essência inelutável que cerraria o círculo da identidade coletiva (a diferença brasileira, tout court), revelando-se, diferentemente, um princípio de sobra, de resto não simbolizável e verdadeiramente produtivo, porque escapa às malhas do discurso metafísico, permitindo que nos refestelemos, neste caso, com o instante do desvio criador. Wisnik verdadeiramente desconstrói o futebol moderno em seu livro, e a diferença, poderíamos lê-la já pensando no valor dos traços abandonados pela escrita desses imaginados poetas da bola, é também uma différance ${ }^{7}$.

Tal questão parece central. Poderíamos arriscar e sugerir que ela ilumina não apenas as traves da obra de Wisnik (seu gol), como ilumina, em retrospecto, toda a fantasia modernista sobre o Brasil: aquela que paira hoje, ainda pujante e viçosa, sobre todos nós, dentro e fora da academia, sejamos mais ou menos treinados nas letras brasileiras.

A importância do passe é tal que devemos permitir-nos aqui uma citação ainda mais longa:

Mas além do poder incoercível do Fado, do acaso irrecorrível que se impõe ao próprio choque aleatório das massas físicas, incluindo a força bruta e a fraqueza psicológica, 
a fração de centímetro ou de segundo, mais a natureza traiçoeira do campo e da bola, tudo repuxando cegamente para um lado ou para outro (em benefício ou em prejuízo do Sobrenatural de Almeida e do Gravatinha [personagens fantásticos de Nelson Rodrigues, que apareceram antes no livro], manifesta-se também no jogo de futebol o acaso ativo da imprevisibilidade produzida, da criação inesperada, que se expressa em dribles, volutas, volteios, firulas, folhas secas, corta-luzes, chapéus e passes inesperados no vazio. Pode-se dizer que, nesse caso, mais do que efetuar o real e o possível, em que o jogo subsiste e insiste, a lógica da diferença produz o virtual e o atual, em que o jogo subitamente existe e acontece.

O princípio da imprevisibilidade conjuga-se originariamente com os componentes malandros, infantis e polimorfos que têm no futebol um campo de expressão criativa, em tensão com os dois princípios anteriores [a "eficiência contabilizável" e a "subjetividade absoluta que atua do alto", subsumidas nas figuras do técnico e do árbitro] (não é à toa a frequência com que se dá a tensão surda ou declarada entre uma mentalidade tático-coletivista programática e a potencialidade criativa do talento surpreendente, castrada e diminuída com indisfarçável prazer pelo planejador previsível) (Idem, pp. 131-132).

Em seguida a essa passagem surge uma das muitas análises de casos concretos: o conflito latente entre Romário e os técnicos Zagallo, Parreira e Felipão. Um conflito que, pela lente do espectador Wisnik, adquire ares quase míticos, ou mais propriamente arquetípicos, como se ali, na figuração dos personagens de carne e osso, se desenrolasse um conflito intemporal, cuja marca é a da castração. Os técnicos, os treinadores, aqueles que planejam, são os castradores. Castradores absolutamente necessários, como em toda constituição psíquica.

Seria entretanto conveniente, neste ponto, perceber que a discussão de Wisnik não é apenas brasileira, por mais que o fantasma do modernismo brasileiro, com seus rasgos inequivocamente nacionalistas, possa assombrar o leitor. A diferença não é, insista-se, um amuleto mágico que pertence ao povo brasileiro. A muiraquitã de Wisnik não se simboliza numa pedra entre maldita e salvadora, ainda que por vezes, em Veneno remédio, o espectro de uma torcida em festa tenda a tomar conta do leitor, empolgado pelas imagens de toda uma experiência que, afinal, começa nas margens, quase literalmente: margens do mar, da sociedade, das normas, da vida adulta. Margens que são e não são brasileiras, pode-se já dizer.

Mas se a "diferença" em questão não éo princípio nacional - aquele que, mais ou menos iludidos, buscavam os hermeneutas clássicos do Brasil -, 
então o que é a tal diferença? Penso que, ao menos neste ponto, a batalha de Wisnik seja também a batalha do pensamento contra si mesmo, uma batalha que, no ambiente acadêmico e intelectual brasileiro, deita raízes na persistente resistência europeia, em especial francesa, contra a tradição racionalista que afinal os próprios franceses representam tão bem. Que se pense na onda fecunda de reações ao cartesianismo na França, desde o século XVII, com céticos e neoepicurianos da mais fina estirpe, para finalmente chegarmos, por vias tortuosas e complexas, àquela crítica profunda ao legado da razão positivista e tecnológica, que tem também na França, em muitos de seus poetas, filósofos e críticos, século XX adentro, artilheiros de primeira linha.

Conviria aqui lembrar a incompreensão e a má vontade de Deleuze, quando, num livro sobre Nietzsche, ele transforma Mallarmé em uma espécie de máximo representante da metafísica, porque a necessidade, ou a finalidade, parece ser, para Deleuze, o que realmente define o poeta do lance de dados (cf. Deleuze, 1977, p. 38). Não cabe aqui entrar em detalhes sobre o que parece ser um pouco de mala leche de Deleuze em relação a Mallarmé. Limitemo-nos apenas ao lance de dados, que afinal simboliza o momento ínfimo e dramático em que o acaso encontra o seu fim, em que a abertura de todas as possibilidades, fornecidas pela combinação dos dados, se fecha na sua finalidade, que é a consumação do lance, quando o azar eis a questão - deve ou não abolir-se. Ao contrário do que sugere Deleuze, parece-me que Mallarmé sabia o poder fecundo do azar - esse mesmo poder que Deleuze sofregamente persegue.

O tema poético é na verdade filosófico e, voltando ao campo (de futebol), ei-nos discutindo em cheio o problema da determinação e da indeterminação, isto é, do potencial absoluto do gênio, daquele jogador único capaz de um desvio absolutamente imprevisto, que em seu instante epifânico é ainda a passagem empolgante do lance no tempo, quando o corpo flutua, imediatamente antes que o quadro se encerre, como se estivéssemos diante de um fim que não se deixa capturar, esquivo entre a pura virtualidade e a atualidade do movimento.

Como bom crítico, Wisnik não está à espera da consumação daquilo que já se previra, ou daquilo que se vira antes. Contudo, se há pouco atribuí ao poeta a capacidade de ver, ou haver visto, o que virá no futuro, estamos aqui, quando se trata da previsão técnica, nos antípodas da visão profética ou poética, que não se baseia afinal na simples confirmação, mas sim numa certeza que jamais existiria sem a fé no milagre. E, de fato, o campo de 
futebol é tão mais empolgante quanto mais próximo esteja de constituir-se em um campo de milagres.

$\mathrm{O}$ crítico, enfim, está em busca, ou à espera (quando busca e espera se juntam, mergulhamos num território que é por direito o da poesia), desses movimentos provenientes de corpos que se liberam fugazmente da previsão castradora da técnica, produzindo instantes de máxima surpresa, de soltura dionisíaca. Todo um potencial se revela aí, a contrapelo não apenas da estrita visão técnica que a tudo prevê e coordena, mas também a contrapelo das visões mais pessimistas sobre o que, afinal, poderíamos fazer das heranças históricas que, queiramos ou não, gostemos delas ou não, são as nossas.

Aí o toque tropicalista, sem o qual não se compreende o potencial liberador que a crítica wisnikiana declara, em alto e bom som, e que entra em conflito, no plano das ideias, com uma vertente do pensamento social que vê a experiência brasileira como uma espécie de falha trágica. Mas se tal vertente do pensamento, tal forma de pensar, tem o Brasil como problema ingente e quase insolúvel, não é tanto porque alguma misteriosa essência ibérica nos amaldiçoaria, mas sim pelas consequências de um desenvolvimento histórico cujos legados seriam, de um lado, o patrimonialismo e o bacharelismo e, de outro, as marcas do passado colonial que funcionariam ainda como grilhões no nosso presente histórico. Aí encontram-se os traços de um debate nem sempre completamente declarado ou assumido, que diz respeito à maneira como o tropicalismo foi, afinal, recebido com desconfiança por parte importante da esquerda brasileira, e não apenas no plano estético.

É no plano político (até onde possamos separá-lo do plano das discussões estéticas, o que é em si um problema teórico espinhoso) que se dá o embate entre visões do mundo e da história diversas. É ainda nesse plano que, ao reclamar uma herança histórica potencialmente benéfica (o veneno convertido em remédio), o otimismo de fundo do impulso tropicalista provoca a reação que reafirma, com as armas da evidência sociológica, o estado deplorável em que nos encontramos, levando em conta aquilo que a experiência histórica brasileira pôde produzir. Trata-se de um embate que se inicia no plano estético, cifrando-se em imagens ora liberadoras ora aprisionadoras, para atingir em cheio questões concernentes ao futuro do país, e ao seu lugar naquilo a que um dia se chamou a marcha das civilizaçôes.

Escavando ainda um tanto a ferida que aí se abre, penso que haja porventura um fantasma - bem uspiano, já se terá notado, ou previsto - a assombrar os escritos de José Miguel Wisnik. Também aqui vale a pena citar abundantemente Veneno remédio: 
Em Caio Prado Júnior, a colonização brasileira é descrita como um capítulo longínquo e deslocado da história mundial do capital, uma empresa que se arma através da "incoerência e instabilidade do povoamento", da "pobreza e miséria na economia", da "dissolução dos costumes" e da "inércia e corrupção nos dirigentes leigos e eclesiásticos" [citações da Formação do Brasil contemporâneo]. Esse aglomerado incoerente e desconexo, mal amalgamado sobre bases precárias, falho de projeto, de justiça, de limite e de caráter, constituindo uma sociedade voltada exclusivamente para a exploração econômica a longa distância, não conhece nenhuma vida popular que não seja a da população degradada pela escravidão, por um lado, e a massa marginal de homens livres sem perspectiva, por outro. Sob o realismo minucioso e implacável do seu crivo produtivista, Caio Prado Júnior não vê lugar para o despontar de alguma produção cultural original. [...] Reconhecemos na visão de Caio Prado Júnior não só uma perspectiva individual, mas também a fundação de um paradigma de abordagem do Brasil, com a sua linhagem crítica correspondente, na qual tem um lugar central a sociologia paulista e uspiana. Nesta, a ênfase recairá na identificação do atraso e do deslocamento brasileiro na ordem mundial, sem privilégio para originalidades culturais populares, consideradas pouco relevantes no quadro econômico e político. O diagnóstico produzirá uma teoria da dependência e uma análise da condição periférica. Se aplicado ao futebol, investe o seu tônus desmistificador na análise das condições socioeconômicas que cercam o esporte, sem chance para a contemplação de redentoras "gingas" e "jeitos de corpo" - e sem atribuir relevância à singularidade da imbricação cultural (Wisnik, 2008, pp. 409-411).

Os fantasmas costumam ser tão mais poderosos quanto mais etéreos sejam. Poderíamos, hoje, quando a década de 1970 (tempo de glória daquela "linhagem crítica" cujo pai fundacional teria sido Caio Prado Júnior) já vai mais ou menos longe, perguntar-nos sobre a prevalência e a permanência do caráter "uspiano" e "paulista" dessa visão em suma pessimista do país.

Convém lembrar, em todo caso, a geografia institucional em meio à qual se gestam os fantasmas que - como ocorre com qualquer fantasma exposto à força da narrativa psicanalítica - disparam mecanismos de defesa, barragens construídas contra um Outro que assoma, no corpo da escrita, como o sintoma de um temor. Pertenço a uma geração diversa e a uma geografia institucional ligeiramente diferente daquela que marca a evolução do pensamento crítico de Wisnik, que, aliás, é por seu turno marcado pelas lentes de um poderoso agente mediador entre os estudos sociais e a literatura, como foi, por muitas décadas, Antonio Candido. 
De toda forma, pertençamos ou não ao círculo em que foram gerados esses debates, a leitura de Veneno remédio ganha muito se tomada em conta certa geografia institucional, que desenha um mapa simbólico complexo, em meio à dura sociologia concreta dos corredores uspianos. É um debate paulista, claro está, mas é também um debate em que estão cifradas as grandes perguntas sobre o futuro do Brasil, assim como neste mesmo debate projeta-se a inquietação com a ideia de uma herança histórica que, uma vez inquirida, reacende paixôes, revive fantasmas e, sobretudo, convida a que falem novamente os três grandes ensaístas cuja leitura o mesmo Antonio Candido, em clássico prefácio, confessou ter formado a imaginação de sua geração: Caio Prado Júnior, Gilberto Freyre e Sérgio Buarque de Holanda (cf. Souza, 2006, p. 235).

Vale a pena notar como, na triangulação entre esses ensaístas, Wisnik vigorosamente recusa a leitura caiopradiana, delicadamente resiste à síntese freyriana e, sugestivamente, fica com a ambiguidade buarquiana, elevando-a a matriz hermenêutica não pelo que ela resolve, mas exatamente pelo que ela se recusa a responder.

Reatando os pontos, resta lembrar que a figuração dos corpos soltos no espaço lembra imediatamente os deuses bailarinos, permitindo flagrar a tela nietzschiana que enforma a imaginação tropicalista de Wisnik, que traz à boca do palco uma soltura ao mesmo tempo divina e profana - propriamente pagã -, que não se deve confundir ao caos epicuriano, em que o movimento é puro e incessante desvio, mas sim ao traçado generoso de um desenho que nos faz crer, a cada instante, que o potencial do gênio vai revelar-se. Logicamente, o potencial do gênio aparece onde não se espera que ele esteja. Ele ocupa um espaço novo, inexistente e impensado antes dele. Este é o convite, porventura, do livro de Wisnik. Convém aceitá-lo momentaneamente, ainda que as teses de fundo de Veneno remédio possam incomodar a não poucos leitores. Parece-me ser este o único caminho de compreensão do livro: perceber que o seu traçado é, ao fim, também uma tentativa angustiada e liberadora de retornar aos grandes ensaios para perquiri-los, testando algo que eles trazem em potência.

Nunca é demais lembrar o papel que as ambiguidades (o veneno que é remédio, uma vez mais) desempenham nas obras que Wisnik chega a considerar e ouvir mais de perto: as de Gilberto Freyre e de Sérgio Buarque de Holanda. Seja dito que as ambiguidades freyrianas, seguidas com cuidado na leitura de Ricardo Benzaquen de Araújo, são vistas num retrospecto que, com bastante propriedade, remonta não apenas a Casa-grande \& senzala, mas também a Sobrados e mucambos. 
Se Wisnik parte de um silêncio significativo em Caio Prado - a voz dos escravos -, é para justamente perceber que aí, nesse vão a que ele chamará provocadoramente de "lugar fora das ideias", Gilberto Freyre encontra sua própria seara: "Gilberto Freyre, a seu modo, e com pressupostos muito diferentes, não faz outra coisa senão dar corpo ao lado dionisíaco dessa presença silenciada em Caio Prado Júnior - a sobra, ou o excedente humano, investida nessa empreitada colonial” (Wisnik, 2008, p. 412). Daí a maestria de uma história da vida privada avant la lettre em Freyre, que busca no recesso doméstico, sem negar o aspecto sádico e contaminado da relação senhor-escravo, uma matriz para a compreensão de uma sociedade em que se misturam o erotismo e o brinquedo de índios, portugueses e negros africanos, tudo temperado pelo despotismo patriarcal brasileiro, atravessado pelos antagonismos que, sabem os leitores de Freyre, são a força de sua prosa e eventualmente de sua mensagem.

Mas aí, numa leitura de fôlego que se resume a alguns parágrafos escritos em tensão exemplar, Wisnik lembra que o equilíbrio de antagonismos, em que se sustenta a sociedade desenhada em Casa-grande \& senzala, perde-se na nova geografia urbana que, no século XIX, marca a "decadência" de todo um mundo, ou todo um projeto, que é justamente o tema de Sobrados e mucambos:

É assim que a europeização dos sobrados, distanciados por sua vez dos mucambos, engata na contramarcha do projeto histórico-ideológico de Gilberto Freyre: no país agora independente, os polos promíscuos de Casa-grande \& senzala se afastam um do outro, perdendo o seu vigor ambivalente e ameaçando cindir aquele fundamento simbiótico e inconsciente que seria, para o ensaísta, o único cimento, ainda que movediço, capaz de constituir uma unidade nacional. A essa linha divergente - civilizadora e europeizante - Gilberto Freyre contrapõe, então, a emergência quase milagrosa, como um deus ex machina que viesse do Hades, e não do alto, o povo mulato (Idem, p. 414).

Aí estão, na leitura atenta do conjunto, o alto e o baixo, figurados nessa peça mulata que, desengonçada (ou talvez cheia de ginga, escondendo alguma insuspeitada perfeição apolínea no corpo feio a quem ninguém dá nada), emerge do fundo dos infernos, e não vem dos céus. Um leitor de Euclides da Cunha lembrará aqui, por certo, do "Hércules-Quasímodo" que é o sertanejo, mas um leitor de Wisnik lembrará, imediatamente, a insistente pergunta sobre o que a música brasileira fez, ou pode fazer, no encontro entre a marca 
"elevada" da vertente erudita e o elemento "baixo" que vem das ruas, daquele fundo caótico em que se agita a experiência popular brasileira, em sua marcha carnavalesca, sincopada e polirrítmica, em meio à qual desponta esse "lugar outro cuja verdade pulsional não há como refugar” (Wisnik, 2004, p. 83).

Aqui poderíamos aventar uma hipótese: ao caráter artificial do mulato como deus ex machina freyriano, Wisnik já respondera, em "Machado maxixe", com aquele mulato genial que, no corpo de uma escrita obediente ao mais culto dos estilos, inscreve, cifrada em ironia e sutileza, a figura de um músico jogado entre o alto e o baixo de suas inspiraçóes e referências. Não esqueçamos que Pestana, o personagem de Machado de Assis em "Um homem célebre", não consegue compor sonatas, porque lhe saem dos dedos lépidos as mais límpidas e saltitantes polcas (em que a marca do maxixe já é evidente, embora não nomeada). Um dia Pestana manda ao diabo as polcas, mas eis que, no que Wisnik chama de um "assombro de ironia" machadiana, as polcas "não quiseram ir tão fundo" (Idem, p. 60).

Tudo o que está nesse universo "baixo", na "profundeza” de uma experiência de ascendência escrava que o superego europeizante oitocentista empurra para baixo do tapete (até aqui componho mais ou menos livremente com as palavras de Wisnik), tudo regressa pelo ladrão do inconsciente, ou ainda, quando já efetuado o desrecalque do modernismo brasileiro, tudo regressa na matéria compósita de uma sempre hipotética cultura brasileira, que por sua vez aponta para o grande projeto de resgate do popular que assombrou, como todos sabemos, Mário de Andrade. Contudo, deixemos Mário para o fim. Fiquemos um tantinho mais com Freyre, ainda aqui através das lentes de Wisnik:

O saldo étnico da "sociedade agrária, escravocrata e híbrida", em sua tardia transição para o moderno, forma a base da operação implícita por meio da qual a obra de Gilberto Freyre realiza o seu desígnio originário inconfessado: algo como a passagem do vira-lata ao vira-ser. Trata-se de apostar na transmutação do povo mestiço desqualificado pelo determinismo científico novecentista [sic], de convertê-lo paradoxalmente no que ele é, de potencializar o fármacon e extrair dos venenos da colonização escravista o remédio da civilização original nos trópicos. Essa reversão estava configurada no modernismo da década de 20: nos termos de Oswald de Andrade, corresponde a devorar a dimensão assustadora do outro, "transformar o tabu em totem”, virar o recalque de ponta-cabeça e converter os próprios entraves traumáticos da formação brasileira em fermento libertador (2008, p. 415). 
Nesse momento, precisamente, Wisnik interrompe a cantiga freyriana, para lembrar que ela viria a desvirtuar-se numa "cristalização ideológica", com a "sublimação estetizada da ameaçadora violência social brasileira, realizada pelo futebol e pela música popular, como uma panaceia políticosocial capaz de harmonizar o país e o perigo de um povo indomado" (Idem, p. 416).

Mas por que a interrupção? Por que o ensaísta evita entregar-se totalmente à cantilena freyriana, por que se manter alerta e recusá-la, despertando no instante mesmo em que ela ameaçava consumir a tudo com seu tocante sonho de uma harmonização universal?

[...] sejam quais forem os limites de sua cristalização ideológica, especialmente $a$ posteriori, os livros de Gilberto Freyre da década de 30 produziram o impacto da instauração de um paradigma apoiado na autorização para saltar ao polo oposto e ver os estigmas da colonização brasileira pelo seu próprio avesso. A violência mestiçante de fundo, uma vez desvelada - e cujo nome, se dito, seria um aterrador estupro amoroso - investe-se de um poder catártico e redentor: um trauma ou um carma histórico do qual terá derivado, paradoxalmente, uma humanidade aberta às diferenças (Idem, p. 416, grifos no original).

Eis a ordem da equação, que se resume na metáfora médica que dá sustentação ao livro: o primeiro diagnóstico, de Caio Prado, estacara no veneno produzido pela formação histórica do Brasil. No segundo diagnóstico, Freyre, guiado desta vez por um otimismo que logo se degradaria em acerbado conservadorismo salazarista, chega ao extremo oposto, sugerindo, conforme a leitura que se faça dele, ser apenas remédio o que produz a nossa estranha sina histórica luso-tropical. Vemo-nos então diante do lugar privilegiado reservado a Sérgio Buarque de Holanda, cuja crucial e radical indefinição leva Wisnik a identificar, no diagnóstico de Raízes do Brasil, o veneno-remédio que lhe fornece o título.

Mais que alongar-nos nas teses de Sérgio Buarque de Holanda, vale lembrar que a presença de Antonio Candido permite, também aqui, interpretar o enigma exposto em Raízes do Brasil. Mas há algo novo na leitura de Wisnik: não é o Candido do famoso prefácio a Raizes do Brasil que fala, mas sim o autor da "Dialética da malandragem". Como se, entre o livro de Sérgio Buarque de Holanda e os demais ensaios daquela época, Wisnik situasse o livro de Manuel Antônio de Almeida, lido pelas lentes de Antonio Candido. O lance é fundamental: 
Foi exatamente isso que Antonio Candido viu no livro, de cuja análise extraiu, na parte final de seu ensaio, uma interpretação de surpreendente acento positivo: sua atmosfera produziria um encantador "mundo sem culpa" de ânimo democrático e tolerante, avesso a estigmatizaçôes e caças a bruxas. Compara o caráter excludente de sociedades puritanas, como a norte-americana monorracial e monorreligiosa (onde a forte introjeção da lei endureceria o indivíduo e o grupo, conferindo certa identidade e resistência, mas desumanizando as relaçôes), com o caráter potencialmente dialógico e aberto da sociabilidade espontânea no Brasil (onde o abrandamento dos choques entre a norma e a conduta desafogaria os conflitos de consciência permitindo maior aceitação do outro). Assim, naquele momento de ditadura em que foi escrito o texto [1970], a "dialética da malandragem" (e o decorrente "mundo sem culpa" ao qual está associada) aparece a Antonio Candido como vantagem sobre a ética protestante e o espírito do capitalismo e como um "trunfo para a hipótese de nos integrarmos num mundo mais aberto" (conforme a resenhou Roberto Schwarz). Inspirado pela leitura das Memórias de um sargento de milícias, Antonio Candido opta, pois, pela tônica afirmativa da ambivalência sérgio-buarquiana e introduz no paradigma uspiano um inusual elogio das peculiaridades brasileiras natas (Idem, p. 424).

“Introduz no paradigma uspiano...". Injetada a droga, a máquina da interpretação desemperra, e o movimento ciclotímico entre o máximo pessimismo e o máximo otimismo (representados pelos dois tempos de Caio Prado Júnior e de Gilberto Freyre - um Freyre sempre mais freyriano que ele mesmo, nunca é demais lembrar) cede, permitindo transitar livremente pela constante transformação do veneno em remédio, e do remédio em veneno. Aí estaria Sérgio Buarque de Holanda, e aí também um momento de rápida e rara aproximação de Wisnik em relação à releitura schwarziana da "Dialética da malandragem". Em sua interpretação do texto de Antonio Candido, Roberto Schwarz teria atentado para o fato de que, sobretudo num estado de exceção, o mundo que se sustenta num espaço anterior às regras leva ao mais puro arbítrio, aquele que termina por justificar o injustificável. A leitura de Schwarz cobrava, de Candido, o que a ditadura cobrava da intelectualidade brasileira: a atenção ao preço dessa liberdade encantatória, que no Brasil pode levar ao pior e ao melhor, como já estava claro, aliás, em Raízes do Brasil ${ }^{8}$.

Wisnik recusa-se, entretanto, a deixar passar a promessa que pulsa, para todos os efeitos, na dialética da malandragem. Tomado de forma não essencialista, em chave propriamente dialética, o movimento livre entre os opostos os tornaria menos extremos, ou, a bem dizer, menos extremados.
8. Além do texto clássico de Schwarz, "Pressupostos, salvo engano, da 'Dialética da malandragem", é obrigatória, aqui, a leitura de Paulo Arantes, com seu Sentimento da dialética na experiência intelectual brasileira. Mais recentemente, a genealogia da dialética da malandragem seria retomada e aprofundada, em uma chave mais filológica, por Leopoldo Waizbort. Cf. Waizbort (2007); Arantes (1992); Schwarz (1987). 
Daí a brincadeira séria de Jorge Mautner - mais um tropicalista a formar no time que, escalado pelo autor de Veneno remédio, rebate o endurecimento de uma leitura do desastre que se encerraria na dialética da ordem e da desordem -, que dizia recentemente que "ou o mundo se brasilifica, ou vira nazista" (cf. Idem, p. 427). O exato oposto, afinal, daquilo que está nas teses mais recentes de Paulo Arantes, que Wisnik refuta com vigor, ou melhor, com ginga:

Sempre se pode dizer que há todas as razões para o pessimismo, menos uma, ou meia: que o jogo só acaba quando termina, como se diz na gíria futebolística, e que ninguém está em posição de dominar todas as suas variáveis. Além disso, a cultura dá sobre os estados das coisas testemunhos às vezes mais interrogantes e inacabados e, por isso mesmo, mais afirmativos do seu estado de acontecimento (Idem, pp. 428-429).

O "estado de acontecimento" convoca novamente aquela virtualidade figurada no movimento ainda inacabado, grávido de consequências inesperadas, que o futebol ofereceria a quem quiser ver, ao menos quando preservado da previsão finalista, da certeza sobre o seu fim. O jogo cultural, o fado incoercível mas misterioso, o drama cifrado da cultura brasileira, permanece em aberto, na pura virtualidade de um movimento cuja finalidade é ainda matéria de debate, mas também de potencial surpresa.

A "diferença" brasileira não é então, tampouco aqui, uma essência ou uma formação determinada que, incontornável, perdura e aponta para o fracasso ou para o sucesso. Diante do fim, há a finta, trazendo de volta ao palco aqueles momentos de soltura dionisíaca, tão ao gosto da experimentação tropicalista. Vale a pena, então, flagrar o momento em que o ensaísta encerra a seção intitulada, justamente, "A diferença", anunciando o que para ele é o Brasil, ou pelo menos o que o Brasil promete:

O princípio do imprevisível se expressa em acontecimentos pontuais, em jogadas de efeito; pode ser visto também no jogo total se olhado como desenho puro, como traçado de linhas intensivas e invisíveis que rasuram o campo todo, como um permanente lance de dados jogados à sorte e ao azar. O gênio da imprevisibilidade às vezes parece morto e renasce com frescor: seu lugar é o eterno retorno. Como já vimos, aí está a fonte daquilo que o futebol pode ter de poesia. O fundamento material e imaterial desse terceiro princípio, em vez da empresa e a instituição universal da lei, é a cultura popular do jogo, incluindo o papel mundialmente 
reconhecido que o Brasil teve no desvelamento da "lógica da diferença" no futebol. Esse assunto será amplamente retomado no próximo capítulo: "A elipse: o futebol brasileiro" (Idem, p. 133).

Novamente a elipse parece ser a figura em que se cifra a experiência brasileira, que certamente não é, e Wisnik o sabe, exclusivamente brasileira, embora tal experiência ganhe seu espaço de honra naquelas "periferias do mundo", em que o "eterno retorno" pode ser muito mais que o regresso fantasmático de uma violência histórica que a visão ufanista da cordialidade (a de Cassiano Ricardo, não a de Sérgio Buarque de Holanda) tende a recalcar. Diferentemente, o "eterno retorno" em questão, com suas cores nietzschianas, remete àquele "lugar fora das ideias", sempre que a virtualidade positiva do desvio for chamada a confirmar a fé na capacidade de contornar, de driblar, de surpreender pela criação de outro mundo, se não alheio, ao menos um tantinho superior ao mundo dominado pela técnica que tudo domina.

Ainda no plano daquilo que o futebol apresenta como possibilidade e virtualidade, não é que o crítico suponha, por um momento sequer, que o universo da técnica, ou a empresa castradora de técnicos e treinadores, seja dispensável. Insista-se na clareza com que Wisnik aponta para uma espécie de constituição psíquica coletiva, cujo ponto saudável seria a realização de uma promessa que ele vê cifrada no futebol brasileiro. Tal promessa depende, como já sugerido, de uma desidealização que, somente ela, poderia levar à feliz conjugação de um esforço geométrico racional, euclidianamente comportado, a uma espécie de variação quântica que a figura do gênio convida a imaginar, em cada lance misterioso diante do qual nos perguntamos, boquiabertos: como diabos o jogador fez isso?

Repiso que não é objetivo deste artigo analisar todo o livro de José Miguel Wisnik. Um livro que, a rigor, vinha apenas se esquentando até esta última passagem citada, e que vai realmente começar a jogar a partir daí, dessa elipse que se anuncia em meio à partida, como uma figura fundamental em que está cifrado o Brasil e suas promessas mais cândidas.

Deixemos então o livro e sua fortuna correrem. As reações a ele serão várias, mas vale a pena saudar, desde já, o lance arriscado e fecundo que é Veneno remédio, no plano da história do pensamento social no Brasil. Afinal, quem ousaria, em pleno início do século XXI, dar continuidade à tradição ensaística dos anos de 1930? Quem se arriscaria a fazê-lo? Em outras palavras: como diabos ele fez isso? 
Antes de dar por encerrada a partida, convém estender-nos em uma necessária e urgente prorrogação.

É de fato impressionante o quadro de referências que vertiginosamente se abrem em Veneno remédio - quadro que este artigo mal começou a deslindar. No livro de José Miguel Wisnik há uma larga discussão especificamente sobre as leituras do futebol, de filósofos, críticos literários e culturais, sociólogos, ensaístas, psicanalistas, historiadores, técnicos, antropólogos, poetas, músicos etc. E há também, como espero ter sugerido, o espectro do modernismo brasileiro, que valeria a pena qualificar, ainda que rapidamente.

Há dois Mários principais, presentes em Veneno remédio. $\mathrm{O}$ primeiro deles, é claro, é o inventor do Macunaíma, em quem o princípio do prazer sintomaticamente sobreleva o princípio da realidade. E aqui vale a pena compreender como, já desde o seu trabalho como pós-graduando (ao mesmo tempo que docente) na Universidade de São Paulo, Wisnik vinha perseguindo na rapsódia de Mário de Andrade, através de uma discussão das leituras de Gilda de Mello e Souza e de Haroldo de Campos, o embate entre um "tempo progressivo" e os "microtempos" que "parecem justamente comparecer à narrativa para resistir à simples consumação das funçôes resolutivas" (Wisnik, 1990, p. 133). Em certo sentido, pode-se ver aí, em germe, aquela preocupação com a temporalidade aberta do movimento em campo, e certa tendência a jogar não apenas em função do gol. Obviamente, a questão toda ganha aqui foros de algo que está para além do campo de futebol.

Ao refletir sobre as categorias proppianas aplicadas por Haroldo de Campos em sua leitura de Macunaima, Wisnik lembra que o termo "polimorfo" conteria em si a proposição de Freud sobre o prazer infantil que, "perversopolimorfo", visa a várias partes do corpo, sem um "acabamento resolutivo". A organização genital adulta, ao contrário, "põe ênfase na finalidade, na resolução orgástica de uma tensão". Trata-se daquilo que, fazendo o meio de campo entre as interpretações conflitantes de Haroldo de Campos e Gilda de Mello e Souza, Wisnik nota como o caráter "prometeico” do herói versus o seu "tempo narcísico" (termos de Gilda; cf. Idem, p. 185), isto é, a tarefa de recuperação do talismã será entrecortada pelos intermináveis desvios criativos e lúdicos que fazem de Macunaíma o que ele é, um antiherói, mas "herói de nossa gente". Em O tupi e o alaúde, ainda segundo a leitura de Wisnik, a prevalência desse segundo tempo "corresponde à carnavalização, pelo colonizado, dos compromissos do tempo progressivo do colonizador, lidos a contrapelo numa lúdica e perversa execução 'de trás 
pra frente' [...]" (Idem, p. 185). Ajustando o foco para aquilo a que venho chamando o espectro modernista, eis aqui, flagrado em filigrana nesta última citação, o módulo antropofágico que permite brincar e, a rigor, regozijar-se com algo que, já pensando numa estranha expressão que foi brinquedo privilegiado na imaginação sociológica brasileira, poderíamos denominar as "vantagens do atraso".

No caso da imaginação sociológica, a "vantagem" estaria, porém, ligada à possibilidade de ver, desde uma periferia que não comunga na ideologia europeia que pressupóe o sujeito livre, o que realmente se esconde no sistema capitalista, que é a exploração extrema do homem pelo homem. Ou então, como no caso da interpretação clássica de Machado de Assis por Roberto Schwarz, essas mesmas ideias girariam em falso, porque a base que elas mistificam simplesmente inexiste num sistema escravista. Trata-se de uma ideologia deslocada, que trabalha sobre o pressuposto de um sujeito livre que não poderia ser sequer postulado em paragens tropicais.

Voltando no entanto a Macunaíma, sua vantagem, se há mesmo uma, está nesse momento anterior à satisfação dos objetivos, nessa espécie de brincadeira (com as ideias e com os corpos) infantil e meio irresponsável, que na leitura de Gilda de Mello e Souza, e na de Wisnik de certa forma, ganha uma coloração positiva. Afinal, é justamente o "desperdício prazeroso" que permite a Macunaíma diferenciar-se de Venceslau Pietro Pietra, que enfrenta a morte "através da acumulação zelosa, do refestelamento na estabilidade, da ocupação do espaço demarcado", enquanto o nosso herói "enfrenta-a em princípio pelo não encouraçamento, pela ocupação permanentemente móvel de todos os espaços” (Idem, p. 187). Nesse momento, podemos dizer que Macunaíma já ia entrando em campo, na imaginação de José Miguel Wisnik. Se alguém duvidar, cito:

O sucesso da luta com o gigante indica o resgate do talismã retido e tamponado na coleção de pedras de Pietro Pietra: sucesso do envolvimento astucioso da realidade pelo prazer, que dribla ao mesmo tempo o mito todo-poderoso do Gigante Piaimã enquanto monstro-engolidor, dribla a ordem capitalista do comerciante Venceslau Pietro Pietra, enveredando pela zona do agrião do vértice capital-carnaval, e numa ágil malandragem, faz o gol (Idem, p. 188).

Claro, nem tudo é alegria no país do futebol. Há o caráter trágico de um herói que ao final queima todas as suas reservas e não chega a lugar nenhum, e Wisnik lembra que Vei, que conduzirá o herói à morte, é a "contrapartida 
polifônica” dessa primeira vitória. Uma vitória a meias, portanto. Mas é a meias que o nosso herói vence, de toda forma.

Wisnik retornaria à questão ainda mais recentemente, numa homenagem póstuma a Gilda de Mello e Souza. Ali, a questão se desvela naquilo a que se poderia chamar, porventura, um elogio da indefinição, que está figurado na imagem de um "ensaio impossível” (o título de sua homenagem), que Gilda nunca escreveu sobre Mário (e que duplica, como aprende o leitor da homenagem de Wisnik, seu próprio ensaio impossível, que é a tese nunca publicada sobre a "dança dramática" em que se imbricam a música e a poesia em Mário de Andrade). Mas eis que a reação de Gilda de Mello e Souza às teses "formalistas" de Haroldo de Campos resultara nessa resposta urgente que é O tupi e o alaúde. Diferentemente de Haroldo, a leitura que Gilda faz de Macunaíma "passava não propriamente por uma poética da forma mas por uma estética da expressão, tendo no seu cerne a interrogação sobre o Brasil e, formando, estruturalmente, o desenho de um xis agônico e conflituoso, condizente com a sua percepção da vida-obra mário-andradina, muito mais interrogativa e dilacerada do que afirmativa" (Wisnik, 2007, pp. 229-230).

Ei-nos novamente diante do xis, da cruz da questão, da variável intraduzível, que no arco mais amplo da literatura brasileira lembrará imediatamente o emplasto Brás Cubas, aquele mesmo que Wisnik associara brincalhonamente (mas há que tomar a brincadeira a sério, quando se trata de um estudioso de Macunaima) ao futebol brasileiro. O emplasto, afinal, iniciara-se com uma ideia que brinca no trapézio da imaginação de Brás, e se estira em xis, resultando na panaceia cujo caráter risível os leitores de Machado conhecem.

Já o caráter de Macunaíma é um problema gritante, um xis irresolvível com o qual nos deparamos a cada instante, quando se inicia, a sério, a aventura hermenêutica de deslindamento do que é, afinal, o enigma brasileiro - o tema modernista por excelência. Se seguirmos as pistas de Gilda, seguidas de perto por Wisnik, veremos que Macunaíma recai, ao fim, numa indefinição, ou numa contradição irresolvível que está ligada a uma decisão constantemente adiada (de crescer, poderíamos já dizer), uma decisão refugada, que o leva à morte.

Se saltamos meio irresponsavelmente de volta ao campo de futebol, a pergunta que resta é sobre o que seria de um país em que todos somos Garrincha, em que a tentação é sempre, diante do gol, retornar e tentar mais uma finta, como se o objetivo se resumisse ao prazer polimorfo do encontro imediato de toda satisfação (a cigarra não pode passar todo o tempo tirando sarro da formiga), ou como se o fim estivesse paradoxalmente fora 
do gol. Este é, em certo sentido, o imbróglio do modernismo brasileiro, que Oswald resolve com graça e sem vergonha alguma por meio da reversão antropofágica, da poesia-exportação, enquanto Mário apenas se angustia, retrocedendo constantemente ao fundo escuro de uma caverna em que a resposta não está à mão. Exagerando nas imagens, e provocando até o aturável, poderíamos dizer que, em Veneno remédio, Wisnik dá as mãos a Mário e tenta trazê-lo de volta do fundo do poço daquela impossibilidade. No entanto, se é verdade que este é o movimento inconfessado de Veneno remédio, não menos verdade é que seria um engano terrível imaginar que Wisnik procure uma remissão, ou uma recuperação do projeto márioandradino. Sua viagem é outra, talvez mesmo porque o tropicalismo fez geleia geral de Mário e Oswald, misturando a felicidade incontida com o que podemos à angústia interminável com o que não podemos ${ }^{9}$. Aí pulsa, quero crer, Veneno remédio. Que Sérgio Buarque de Holanda dê a resposta final (conclusiva na sua inconclusão), é já um problema em que deve o leitor pensar, depois de ler o livro de José Miguel Wisnik.

Mas há ainda outro Mário no livro: o irmão de Nelson Rodrigues, Mário Filho, que teria como ninguém acompanhado aquele momento em que as linhas fortes do sonho modernista no Brasil se definiam, sobretudo a partir do Rio de Janeiro, onde Manuel Bandeira se encontrava com Sinhô, Donga, Freyre, Sérgio Buarque de Holanda, Prudente de Moraes, neto, Villa-Lobos, Pixinguinha. Aqueles interessados na história do modernismo brasileiro sabem que esses encontros são às vezes elevados a um plano quase mítico, fundacional (cf. Vianna, 1995), mas o que deve interessar-nos aqui não é a reconstituição desses encontros miríficos, e nem mesmo a crítica de uma visão sobre o modernismo que tem a ver com o encontro pacífico em que a realidade das classes sociais repentinamente desaparece, numa fantasia empolgante que a ideia freyriana de uma "democracia social" condensa com felicidade.

Vale a pena atentar para um último ponto curioso que, salvo engano, conecta Veneno remédio a uma longa tradição da imaginação brasileira, cujo momento fundamental está, insista-se, no modernismo. Trata-se do fato de que toda a fantasia dessa diferença - mesmo a "diferença" nos termos em nada essencialistas de Wisnik - é disparada a partir ainda de um princípio lógico identitário. Há, quase invariavelmente, um Outro que se entremostra, tímido - ora ridículo, ora ameaçador -, mas que, na sua alteridade, é ainda a projeção daquilo de que nos desviamos. Ou daquilo de que a nossa confusa modernidade tropical permitiria um dia desviar-nos. Trata-se, em suma, do
9. A insistência em torno da matriz tropicalista de Wisnik tem a ver com sua própria reação à minha fala na USP, de que se originou este artigo. Diante de uma aproximação que tentei entre o projeto mário-andradino de resgate da cultura brasileira e o que pulsa nos escritos de Wisnik, ele reagiu vigorosamente, reclamando-se um "tropicalista". De fato, a tragédia para Mário de Andrade era a aposta, fadada ao fracasso, em um elemento telúrico (a rigor, rural) que formaria a base de um edifício cultural minimamente orgânico. Sabemos que o tropicalismo rompe com o fundo purista dessa tendência, abrindo-se generosamente (os críticos dirão "acriticamente") ao que vem de fora, nutrindo-se na sensibilidade da arte pop diante daquilo que o mundo midiático e de massas podia oferecer, convertendo o que os críticos mais sisudos chamariam de "lixo cultural" em tesouro a trabalhar. Talvez seja correto dizer que Wisnik se situa a meio caminho, ou a cavaleiro dessas duas tendências, porque a sua busca (e aqui o músico e o crítico definitivamente são o mesmo) retorna à água todavia pura de uma canção que se gesta no meio urbano, que já habita aquele espaço que, para Mário de Andrade, ameaçava o que tínhamos de mais precioso. As muiraquitãs são um pouco diversas, nos três casos; mas todas vêm com os seus gigantes. 
mundo da técnica, dos treinamentos, da previsibilidade, das regras claras e dos que as seguem cegamente - esse mundo enfim que faz e não nos faz falta, de que precisamos e que ao mesmo tempo recusamos. Para relembrar a tirada de Fernando Novais, se nos entregamos a ele, não somos mais Brasil, se somos Brasil, esse mesmo mundo desencantado nos faz uma falta terrível.

Mas que mundo é esse? Abre-se aí toda uma discussão de que este artigo não dará conta, já que a partida se encerra em alguns instantes. Mas é claro que esse mundo é o mundo desencantado, esvaziado de toda humanidade, de todo segredo. Um mundo que nossa imaginação parece fadada a localizar sempre do lado de lá: o que está depois dos Pireneus, a Europa, o mundo desenvolvido, os Estados Unidos, o capitalismo. Note-se que todos os termos com que poderíamos nomear esse "outro lado" evocam a figura castradora. Mas nós sabemos que a piada e o deboche diante do Pai é sempre a face leve de algo mais profundo, que é o temor dele, e o temor de um dia parecer-se a ele.

Neste ponto, e ainda no espectro de uma leitura de algo a que se poderia chamar "as heranças de Raízes do Brasil", lembro Richard Morse, que foi quem mais longe levou o sonho dessa diferença (mais que brasileira, iberoamericana), que se constrói espetacularmente, e especularmente, contra a imagem dos Estados Unidos, contra esse Outro que é um referente muitas vezes silencioso de nossa história, talvez porque nós nunca deixaremos de acreditar que somos uma alternativa a eles.

Ao encerrar um texto da década de 1980, sobre "uma nova ideologia" concebida a partir da discussão das tradições intelectuais diversas da América Latina e dos Estados Unidos, Richard Morse de repente se vê obrigado a recorrer à música:

Como, então, pode a ideologia - no sentido de um conjunto de regras universais do jogo político - florescer em sociedades que são verdadeiramente plurais, e não apenas faccionalizadas?

Encontramos uma pista no contraste estabelecido por Chernoff entre a música ocidental e a africana, cujas implicações são claras para os países afro-antilhanos e o Brasil. Por ora, e talvez durante todo o nosso futuro existencial, não podemos ter esperanças de encontrar alternativas nítidas e práticas. Precisamos é de sensibilidade para construções e ritmos simultâneos. Isto é o que encontramos na comparação feita por Chernoff entre o "sentido do metrônomo" ocidental, que conceitua o tempo como algo que caminha inexoravelmente rumo a um momento distante, e a música africana, que impóe ao músico e ao espectador a necessidade de manter um 
ritmo pessoal que dê coerência a um complexo de ritmos e acentuações em conflito. A música ocidental harmoniza tons diferentes em acordes, mas não dá nomes aos ritmos; sua terminologia (acelerando, rubato, síncope etc.) refere-se à velocidade, ao metro e à acentuação. Na África, os compassos têm nomes e variações, e o compasso da música é resultado de uma relação entre ritmos e não de um padrão dominante. As alternativas permanecem vivas. Traduzida em termos sociopolíticos, esta é a metáfora que esclarece nosso caso (Morse, 1990, pp. 203-204).

Pouco interessa a imprecisão da análise de Morse do ponto de vista musical. Aliás, pouco interessa a precisão, sob qualquer aspecto, porque é evidente que aqui, como em tantos momentos na obra de Richard Morse, estamos diante de um rasgo poético, de uma angustiada tentativa de compreender a promessa que se engendra ao Sul do mundo. Uma promessa secretada, ou segredada, fora daquele território de que ele, Morse, provém: os Estados Unidos da América. Nesse sentido, Morse é como um filho desditado que enlouquece, tomado da fúria de compreensão daquele Outro que, para ele, Morse, somos nós, brasileiros, latino-americanos.

De fato, o drible, a finta, a blague, a síncope - como se queira chamar -, convoca a ideia de um desvio que, como aquele "valor $\pi$ antropológico" de Wisnik, como aquela (in)diferença produtiva, convida à imaginação de outro mundo, que não estava lá, e que de repente, por um passe meio mágico, se concretiza diante de nossas vistas. É interessante que, num historiador em geral criterioso como Morse, esse "outro mundo" que a experiência iberoamericana oferece seja anunciado primeiro pela ficção. Em Richard Morse, é a literatura que anuncia aquilo que virá.

Os poetas e romancistas, num espectro latino-americanista que inclui as elipses do neobarroco hispano-americano, desenham o mundo que poderia ser (cf. Morse, 1988): mais ou menos como o futebol de Wisnik, que anuncia tudo aquilo que é tramado pelo desejo de um mundo melhor, mas forjado nas suas periferias. Um desejo que não é apenas de recuperação daquele gap civilizacional, político, dos direitos que faltam a quem deles precisa. Um desejo que, a despeito de seus rasgos generosos, é também uma vontade surda e profunda de reagir ao outro lado do espelho, àquela civilização que teima em não compreender o nosso jogo, porque é afinal uma nação - os Estados Unidos da América - que, para jogar ainda uma vez com a expressão de Wisnik, "não brinca em serviço" (Wisnik, 2008, p. 149).

Não se trata de questionar, ou de corroborar a visão de José Miguel Wisnik em relação aos Estados Unidos, mas sim de perguntar-nos o que os 
Estados Unidos carregam de nossos maiores temores e de nossas maiores resistências - mas talvez, como em toda lógica desse tipo de aproximação, dos nossos mais recônditos desejos também.

Enfim, encerro afirmando que meu objetivo com este artigo é duplo: em primeiro lugar, reconhecer que finalmente veio à luz uma obra do quilate de Veneno remédio, que recupera a grande aventura hermenêutica brasileira, e a atualiza em termos que são e não são os termos modernistas; em segundo lugar, reconhecer também, ou antes sugerir, que o livro se constrói a partir de uma fantasia (e haverá livro digno desse nome que não se construa a partir de uma fantasia?) que poderíamos nomear modernista, no seu espectro brasileiro, que tem a ver com a reação mais profunda, pela via da alegria que é a prova dos nove, ao mundo desencantado em que o sentido se desfez. Que esse mundo desencantado e sem sentido não seja o nosso, e sim o mundo dos outros, daqueles que estão para lá de uma linha que nos separa deles, é um problema em si intrincado, que todos nós talvez mal tenhamos começado a compreender.

\section{Referências Bibliográficas}

Adorno, Theodor. (1991), "The essay as form”. Tradução de Shierry Weber Nicholsen. In: Notes to Literature, 1. New York, Columbia University Press, pp. 3-23.

Arantes, Paulo Eduardo. (1992), Sentimento da dialética na experiência intelectual brasileira: dialética e dualidade segundo Antonio Candido e Roberto Schwarz. Rio de Janeiro, Paz e Terra.

Araújo, Ricardo Benzaquen de. (1994), Guerra e paz: Casa-grande \& senzala e a obra de Gilberto Freyre nos anos 30. Rio de Janeiro, Editora 34.

BнавнА, Homi K. (1990), "DissemiNation: time, narrative, and the margins of the modern nation". In: Nation and Narration. London, Routledge, pp. 291-322.

Deleuze, Gilles. (1977), Nietzsche et la philosophie. Paris, Presses Universitaires de France.

Derrida, Jacques. (1972), "La pharmacie de Platon”. In: La dissémination. Paris, Seuil, pp. 74-196. (1979), L'écriture et la différence. Paris, Seuil.

FREYRE, Gilberto. (2003), Sobrados e mucambos: decadência do patriarcado rural e desenvolvimento do urbano. São Paulo, Global.

Holanda, Sérgio Buarque de. (1996), “Ariel”. In: O espirito e a letra: estudos de crítica literária. Edição de Antonio Arnoni Prado. São Paulo, Companhia das Letras, pp. 42-46. 
(2006), Raízes do Brasil. Edição de Ricardo Benzaquen de Araújo e Lilia Schwarcz. São Paulo, Companhia das Letras.

Monteiro, Pedro Meira. (2009), "As Raizes do Brasil no Espelho de Próspero". Novos Estudos - Cebrap. São Paulo, 83: 159-182, mar.

Morse, Richard. (1988), O espelho de Próspero: cultura e ideias nas Américas. São Paulo, Companhia das Letras. (1990), "Apontamentos para uma nova ideologia". In: A volta de McLuhanaima: cinco estudos solenes e uma brincadeira séria. São Paulo, Companhia das Letras, pp. 161-204.

Santiago, Silviano. (2006), As raizes e o labirinto da América Latina. Rio de Janeiro, Rocco.

SCHWARZ, Roberto. (1981), Ao vencedor as batatas: forma literária e processo social nos inícios do romance brasileiro. São Paulo, Duas Cidades. (1987), "Pressupostos, salvo engano, de 'Dialética da malandragem”". In: Que horas são? São Paulo, Companhia das Letras, pp. 129-155.

SouzA, Antonio Candido de Mello e. (1993), “Dialética da malandragem”. In:

$O$ discurso e a cidade. São Paulo, Duas Cidades, pp. 19-54.

(2006), “O significado de Raízes do Brasil’. In: Holanda, Sérgio Buarque de.

Raizes do Brasil. Edição de Ricardo Benzaquen de Araújo e Lilia Schwarcz. São Paulo, Companhia das Letras, pp. 235-250.

SouZA, Gilda de Mello e. (1979), O tupi e o alaúde: uma interpretação de Macunaíma.

São Paulo, Duas Cidades.

Vianna, Hermano. (1995), O mistério do samba. Rio de Janeiro, Zahar.

Waizbort, Leopoldo. (2007), A passagem do três ao um: crítica literária, sociologia, filologia. São Paulo, Cosac Naify.

WisniK, José Miguel. (1990), "A rotação das utopias-rapsódia”. In: BERRIEL, Carlos

Eduardo O. (org.), Mário de Andradelhoje. São Paulo, Ensaio, pp. 179-193. (1999), O som e o sentido: uma outra história das músicas. $1^{a}$ edição 1989. São

Paulo, Companhia das Letras. . (2004), Sem receita: ensaios e cançôes São Paulo, Publifolha. . (2007), “O ensaio impossível”. In: Miceli, Sergio e Mattos, Franklin de (org.), Gilda, a paixão pela forma. Rio de Janeiro, Ouro sobre Azul, pp. 209-235. (2008), Veneno remédio: o futebol e o Brasil. São Paulo, Companhia das Letras. 


\section{Resumo}

O modernismo entra em campo: o caso Wisnik

Neste artigo, discuto o livro de José Miguel Wisnik, Veneno remédio: o futebol e o Brasil, publicado em 2008. Noto como, nele, a discussão do futebol permite retomar impasses já trabalhados pelos modernistas, revivendo algumas de suas angústias fundamentais. Analiso ainda como o livro se põe na linhagem das grandes inquirições sobre o Brasil, rebatendo criticamente o esforço hermenêutico dos nossos ensaístas clássicos.

Palavras-chave: Pensamento social brasileiro; Futebol; José Miguel Wisnik; Sérgio Buarque de Holanda; Gilberto Freyre; Mário de Andrade.

\section{Abstract}

Modernism in focus: the Wisnik case

In this article I discuss José Miguel Wisnik’s book, Veneno remédio: o futebol e o Brasil [Poison cure: football and Brazil], published in 2008. I point out how the work's discussion of football enables a new approach to impasses already explored by modernists, reviving some of their fundamental uncertainties. I also analyze how the book forms part of the lineage of great inquiries into Brazil by refuting the hermeneutic enterprise of our classic essayists.

Keywords: Brazilian social thought; Football; José Miguel Wisnik; Sérgio Buarque de Holanda; Gilberto Freyre; Mário de Andrade. 